\title{
NEEDLE ANATOMY SUGGESTS HYBRIDIZATION BETWEEN THE RELICT TURFOSA FORM OF PINUS SYLVESTRIS L. FROM THE GAZZWA PEAT BOG AND TYPICAL SCOTS PINE
}

\author{
Lech Urbaniak ${ }^{1}$, Marta PrZybyŁa ${ }^{1}$, WŁodzimierz PisareK ${ }^{2}$, \\ EWA CHUDZINSKA ${ }^{1}$, ROMAN ZIELINSKI ${ }^{3}$, KORNELIA POLOK ${ }^{3}$ \\ ${ }^{1}$ Department of Genetics, Adam Mickiewicz University \\ Umultowska 89, 61-614 Poznań, Poland \\ 2 Department of Botany and Nature Protection, University of Warmia and Mazury in Olsztyn \\ Plac Łódzki 1, 10-727 Olsztyn, Poland \\ ${ }^{3}$ Department of Genetics, University of Warmia and Mazury in Olsztyn \\ Plac Łódzki 3, 10-967 Olsztyn, Poland \\ e-mail:kpolok@uwm.edu.pl
}

(Received: April 14, 2008. Accepted: December 17, 2008)

\begin{abstract}
The aim of this study was to characterize the turfosa form of Pinus sylvestris from the Gązwa peat bog reserve in terms of 16 anatomical needle traits and to determine whether pines with a typical morphotype inhabiting the peat bog have been so successful thanks to hybridization with the unique turfosa ecotype. Investigations were conducted on three phenotypic groups of Scots pine growing in the peat bog. The first two groups consisted of 30 turfosa trees at the age of 117-217 years and 20 trees at the age of 30-85 years. The third group consisted of typical pines represented by 10 trees at the age of 20-55 years. In total 30 trees of typical pine, surrounding the peat bog, at the age of 100-150 years served as outgroup. Descriptive statistics, analysis of variance with the F test, Tukey's test, and a number of multivariate analyses were used to estimate differences between the studied groups of trees based on 16 anatomical needle characteristics. The old turfosa form from the Gązwa reserve proved to be a unique and relict peat bog pine, as it was shown by the differences in 10 analyzed needle traits in comparison to pine with a typical morphotype growing in the areas surrounding the peat bog. The young typical pines have adapted to conditions found in the peat bog owing to hybridization with the turfosa forms. The young turfosa trees differed from the old turfosa trees and also they have probably been of a hybrid origin. The old turfosa form from the Gązwa reserve is a threatened ecotype due to its hybridization with pines from the population surrounding the peat bog.
\end{abstract}

KEY WORDS: Pinus sylvestris f. turfosa (Woerl.), typical Scots pine, needle anatomy, quantitative traits, hybridization, threatened ecotype.

\section{INTRODUCTION}

Climatic changes in the last phase of the Pleistocene and the beginning of the Holocene to a considerable degree determined the present-day range of typical pine and its variation (Huntley and Birks 1983; Staszkiewicz 1993; Urbaniak 1998). In central-eastern Europe in that time the dynamics of migration processes, also as a consequence of the merging of gene pools of Scots pine populations differing in origin, was high. Populations of that species were subjected to multifactorial selection pressure. It resulted, among others, from the changeable climate of European lowlands adjacent to the southern part of the Baltic Sea and the competition of broad-leaved trees (Giertych 1979; Mojski 1993).
Scots pine had already inhabited the area of present-day Poland in the prearboreal period, approximately 10000 years ago (Szymański 1996). In the first stage, the expansion of this species was limited probably only to mineral soils. Later, when first peat bogs were formed, pine could penetrate also those areas. The first peat bogs characterized by a considerable share of peat mosses in the moss layer were formed at the turn of the boreal and Atlantic periods, i.e., about 8500 years ago (Tobolski 2003, 2006). However, they were only scarce transitional moors of limnogenic origin. The development of typical high peat bogs on a larger scale and a possibility of their colonization by pine occurred slightly later. At present it is difficult to determine the exact point in a time scale when it occurred, as the problem has not been thoroughly investigated. 
The oldest documented high peat bog sites in northern Poland have come from the end of the Atlantic period and the beginning of the subboreal period, dated to approximately 3000 years ago (Herbichowa 1998). At least since then the inhabitation and development of Scots pine on peat bogs have been promoted by favorable conditions in the young glacial areas. Undoubtedly, these conditions were found even earlier in the south of the last glaciation boundary (Kondracki 1998).

Habitat conditions observed in high peat bogs differ markedly from those in mineral soils, on which Scots pine occurs commonly. Moreover, peatlands resisted the economic impact of man and interference into the structure and stability of local Scots pine populations for a longer time.

Peat bog populations of Scots pine have adapted to specific, but stable conditions found in mossy bogs, which is manifested in their longevity, exceeding even 250 years (Polok et al. 2005). The morphological distinctness of certain populations of peat bog pines has been the basis for their separation as forms or varieties (Jasnowski et al. 1968; Staszkiewicz 1970). Private DNA fingerprints coupled with differences in needle morphology in comparison with typical Scots pine provide further credence that the adaptation of $P$. sylvestris to peat bog conditions may be determined genetically (Polok et al. 2005; Zielinski et al. 2007).

The peat bog form of Scots pine (Pinus sylvestris f. turfosa Woerl.) generally does not reach considerable height, the upper part of its stems are characteristically twisted, frequently with umbrella-shaped crowns, with short needles of approximately 3-4 cm in length, as well as small and numerous cones (Staszkiewicz 1970). Its characteristic features include as well slow growth and low stem growth rate (Polok et al. 2005). The turfosa form is found in Poland in high peat bogs (Jasnowski et al. 1968).

The Gązwa high peat bog reserve, located in north-eastern Poland (the Warmia-Mazury Province), $60 \mathrm{~km}$ from the city of Olsztyn is one of the richest sites where the turfosa form of Scots pine is found. Peat bog phenotypes of Scots pine are still common there, however, they are no longer dominant components of the $P$. sylvestris population. On the contrary, in the first half of the 20th century $P$. sylvestris f. turfosa forming a sparse low stand was the only pine inhabiting the peat bog (Młynek and Polakowski 1962). Partial drainage of the Gazwa area connected with peat digging already before the Second World War and further land reclamation conducted in the second half of the 20th century initiated a slow, but regular degradation of this bog. This has led, among others, to the invasion into this area of pines with a typical phenotype, at present being up to 55 years old and constituting a dominant element of the peat bog.

At the fringes of the Gązwa peat bog and islands located in its central mineral part also older straight-grown pines are found.

Apart from the turfosa form and typical pines, also pines representing a wide range of morphological variation are observed in the Gązwa peat bog, including intermediate forms and trees more or less similar to either of the two above mentioned phenotypes. It can not be excluded that this variation is a consequence of hybridization between typical Scots pine and the turfosa form. This is suggested by the intermediate needle morphology of "look like typical" young pines growing in the peat bog. These young trees possess DNA markers unique both for typical Scots pine and peat bog phenotype (Polok et al. 2005; Zielinski et al. 2007).

The fact that in the Gązwa peat bog phenotypically different groups of probably hybridizing trees are growing in close proximity constitutes a convenient experimental system with properties of comparative cultures, especially suitable for biometric studies. Needle anatomical characteristics are commonly used to assess the diversity of pine populations due to their low susceptibility to the modifying effect of environmental factors (Bobowicz 1990; Urbaniak 1998). This justifies the application of these traits to compare groups of trees differing in their phenotypes, growing in the Gązwa reserve.

Therefore, the studies were aimed at search for diagnostic traits in needle anatomy, typical of the turfosa form. Such characters could confirm its distinctiveness and help to determine whether pines of the typical phenotype growing in the Gązwa peat bog are successful owing to hybridization with this unique ecotype. The possibility of hybridization might be a serious threat for further survival of the turfosa form in this peat bog. It would further justify appropriate actions aimed to preserve this unique ecotype.

\section{MATERIALS AND METHODS}

\section{Material description}

Two-year old needles of Scots pine, Pinus sylvestris (L.), were collected for anatomical analyses in March, 2004 and 2005 in the Gązwa peat bog reserve from two concurrent populations i.e., a population inhabiting the peat bog and a population surrounding the peat bog and growing on mineral soil. The first of them was represented by three phenotypic groups (Polok et al. 2005).

\section{Characteristics of three phenotypic groups of Scots pine constituting the population found in the peat bog}

Turfosa form (Woerl.), the old trees

For the purpose of analysis a total of 30 specimens were selected with a morphotype characteristic for the turfosa form, short (approximately $7 \mathrm{~m}$ high), a curved and crooked stem, twisted along its axis, devoid of branch fascicles, and an irregular, umbrella-shaped crown. These trees exhibited a slow growth rate. They were the oldest trees found in the peat bog. Their age ranged from 117 to 217 years (mean 156 years).

\section{Turfosa form (Woerl.), the young trees}

This group was represented by 20 trees, exhibiting considerable phenotypic similarity to the old trees of the turfosa form. However, they were much younger. Their age ranged from 30 to 85 years (mean 48 years) and their height ranged from 0.5 to $4 \mathrm{~m}$ (mean $1.6 \mathrm{~m}$ ).

Typical Scots pine, the young trees

This group was composed of 10 trees, which exhibited phenotypic similarity to pines with a typical habitus growing on mineral soils. They had straight-grown stems and regular, well-developed nodes with preserved branch fascicles. Their internodes were elongated, which resulted from fast shoot growth. Their age ranged from 20 to 55 ye- 
TABLE 1. Basic statistics of 16 anatomical needle traits of four Scots pine phenotypic groups.

\begin{tabular}{|c|c|c|c|c|c|c|}
\hline Trait & Group & Mean & Minimum & Maximum & $\begin{array}{l}\text { Standard } \\
\text { deviation }\end{array}$ & $\begin{array}{c}\text { Variation } \\
\text { coefficient } \\
{[\%]}\end{array}$ \\
\hline & Turfosa form, old trees & $1412.4^{\mathrm{a}}$ & 1218 & 1620 & 102.7 & 7.27 \\
\hline \multirow{3}{*}{$\begin{array}{l}\text { Width of needle } \\
\text { cross-section } \\
{[\mu \mathrm{m}]}\end{array}$} & Turfosa form, young trees & $1345.8^{\mathrm{a}}$ & 1140 & 1500 & 105.8 & 7.86 \\
\hline & Typical pine, young trees & $1407.5^{\mathrm{a}}$ & 1255 & 1520 & 80.9 & 5.75 \\
\hline & Typical surrounding pine, old trees & $1095.3^{b}$ & 508 & 1370 & 159.8 & 14.59 \\
\hline \multirow{4}{*}{$\begin{array}{l}2 \\
\text { Height of needle } \\
\text { cross-section } \\
{[\mu \mathrm{m}]}\end{array}$} & Turfosa form, old trees & $673.7^{\mathrm{a}}$ & 580 & 740 & 41.5 & 6.17 \\
\hline & Turfosa form, young trees & $648.8^{\mathrm{ab}}$ & 525 & 730 & 50.3 & 7.75 \\
\hline & Typical pine, young trees & $629.5^{b}$ & 570 & 695 & 40.5 & 6.44 \\
\hline & Typical surrounding pine, old trees & $545.8^{\mathrm{c}}$ & 224 & 675 & 75.0 & 13.75 \\
\hline \multirow{4}{*}{$\begin{array}{c}3 \\
\text { The ratio of height of needle } \\
\text { cross-section to width } \\
\text { of needle cross-section } \\
{[\mu \mathrm{m}]}\end{array}$} & Turfosa form, old trees & $0.48^{\mathrm{b}}$ & 0.41 & 0.53 & 0.03 & 5.90 \\
\hline & Turfosa form, young treesa & $0.48^{\mathrm{ab}}$ & 0.44 & 0.54 & 0.03 & 6.60 \\
\hline & Typical pine, young trees & $0.45^{\mathrm{c}}$ & 0.41 & 0.49 & 0.03 & 5.72 \\
\hline & Typical surrounding pine, old trees & $0.50^{\mathrm{a}}$ & 0.42 & 0.58 & 0.04 & 7.42 \\
\hline \multirow{4}{*}{$\begin{array}{c}4 \\
\text { Number of resin ducts } \\
{[\mathrm{n}]}\end{array}$} & Turfosa form. old trees & $14.7^{\mathrm{a}}$ & 9.0 & 20.2 & 2.6 & 17.69 \\
\hline & Turfosa form, young trees & $12.1^{b}$ & 7.6 & 18.2 & 2.6 & 21.82 \\
\hline & Typical pine, young trees & $12.3^{\mathrm{b}}$ & 8.7 & 15.5 & 2.4 & 19.81 \\
\hline & Typical surrounding pine, old trees & $9.8^{\mathrm{c}}$ & 7.2 & 18.2 & 2.4 & 23.92 \\
\hline \multirow{4}{*}{$\begin{array}{l}5 \\
\text { Lumen width of } 1 \mathrm{st} \\
\text { resin duct } \\
{[\mu \mathrm{m}]}\end{array}$} & Turfosa form. old trees & 63.3 & 44 & 81 & 8.6 & 13.63 \\
\hline & Turfosa form, young trees & 61.8 & 46 & 82 & 9.6 & 15.61 \\
\hline & Typical pine, young trees & 56.6 & 44 & 64 & 6.6 & 11.73 \\
\hline & Typical surrounding pine, old trees & 60.3 & 37 & 124 & 15.8 & 26.24 \\
\hline \multirow{4}{*}{$\begin{array}{c}6 \\
\text { Lumen width of 1st } \\
\text { resin duct including sclerenchyma } \\
{[\mu \mathrm{m}]}\end{array}$} & Turfosa form. old trees & 100.0 & 68 & 123 & 12.4 & 12.40 \\
\hline & Turfosa form, young trees & 101.8 & 79 & 123 & 10.9 & 10.77 \\
\hline & Typical pine, young trees & 94.3 & 77 & 105 & 8.2 & 8.66 \\
\hline & Typical surrounding pine, old trees & 100.3 & 58 & 214 & 25.9 & 25.83 \\
\hline \multirow{4}{*}{$\begin{array}{l}7 \\
\text { Lumen width of } 2 \mathrm{nd} \\
\text { resin duct } \\
{[\mu \mathrm{m}]}\end{array}$} & Turfosa form, old trees & 63.9 & 51 & 86 & 7.7 & 11.99 \\
\hline & Turfosa form,young trees & 60.5 & 47 & 85 & 9.9 & 16.47 \\
\hline & Typical pine, young trees & 56.3 & 49 & 65 & 5.3 & 9.44 \\
\hline & Typical surrounding pine, old trees & 61.0 & 8 & 124 & 18.6 & 30.43 \\
\hline \multirow{4}{*}{$\begin{array}{c}8 \\
\text { Lumen width of 2nd } \\
\text { resin duct including sclerenchyma } \\
{[\mu \mathrm{m}]}\end{array}$} & Turfosa form, old trees & 100.7 & 72 & 134 & 12.1 & 12.03 \\
\hline & Turfosa form, young trees & 101.1 & 78 & 127 & 12.8 & 12.70 \\
\hline & Typical pine, young trees & 96.5 & 85 & 106 & 7.8 & 8.05 \\
\hline & Typical surrounding pine, old trees & 102.55 & 77 & 220 & 25.7 & 25.04 \\
\hline \multirow{4}{*}{$\begin{array}{l}9 \\
\text { Lumen width of 3rd } \\
\text { resin duct } \\
{[\mu \mathrm{m}]}\end{array}$} & Turfosa form, old trees & 41.7 & 30 & 55 & 7.1 & 16.95 \\
\hline & Turfosa form, young trees & 38.4 & 18 & 52 & 10.0 & 26.07 \\
\hline & Typical pine, young trees & 33.1 & 9 & 53 & 12.9 & 38.96 \\
\hline & Typical surrounding pine, old trees & 37.7 & 19 & 82 & 11.4 & 30.28 \\
\hline \multirow{4}{*}{$\begin{array}{l}\text { Lumen width of 3rd } \\
\text { resin duct including sclerenchyma } \\
{[\mu \mathrm{m}]}\end{array}$} & Turfosa form, old trees & 76.3 & 59 & 95 & 9.9 & 13.09 \\
\hline & Turfosa form, young trees & 73.2 & 36 & 95 & 16.1 & 21.96 \\
\hline & Typical pine, young trees & 64.5 & 24 & 91 & 21.0 & 32.61 \\
\hline & Typical surrounding pine, old trees & 72.0 & 48 & 152 & 18.5 & 25.74 \\
\hline \multirow{4}{*}{$\begin{array}{c}11 \\
\text { Epidermis with cuticula } \\
\text { thickness on flat side of needle } \\
{[\mu \mathrm{m}]}\end{array}$} & Turfosa form, old trees & $29.6^{\mathrm{a}}$ & 23 & 40 & 4.1 & 13.98 \\
\hline & Turfosa form, young trees & $28.2^{\mathrm{a}}$ & 23 & 33 & 2.4 & 8.52 \\
\hline & Typical pine, young trees & $29.6^{\mathrm{a}}$ & 28 & 32 & 1.4 & 4.76 \\
\hline & Typical surrounding pine, old trees & $25.6^{\mathrm{b}}$ & 22 & 29 & 1.8 & 7.07 \\
\hline \multirow{4}{*}{$\begin{array}{c}12 \\
\text { Three epidermal cells } \\
\text { width on flat side of needle } \\
\text { [ } \mu \mathrm{m}]\end{array}$} & Turfosa form, old trees & $53.6^{\mathrm{a}}$ & 40 & 78 & 8.1 & 15.04 \\
\hline & Turfosa form, young trees & $53.5^{\mathrm{a}}$ & 49 & 62 & 3.5 & 6.57 \\
\hline & Typical pine, young trees & $52.3^{\mathrm{a}}$ & 47 & 64 & 5.4 & 10.23 \\
\hline & Typical surrounding pine, old trees & $47.5^{b}$ & 27 & 57 & 6.3 & 13.21 \\
\hline \multirow{4}{*}{$\begin{array}{c}13 \\
\text { Height } \\
\text { of vascular cylinder } \\
{[\mu \mathrm{m}]}\end{array}$} & Turfosa form, old trees & $292.2^{\mathrm{ab}}$ & 242 & 332 & 24.17 & 8.27 \\
\hline & Turfosa form, young trees & $295.8^{\mathrm{a}}$ & 250 & 338 & 25.05 & 8.47 \\
\hline & Typical pine, young trees & $276.2^{\mathrm{b}}$ & 266 & 288 & 7.02 & 2.54 \\
\hline & Typical surrounding pine, old trees & $258.5^{\mathrm{c}}$ & 218 & 316 & 21.87 & 8.46 \\
\hline
\end{tabular}


TABLE 1. Cont.

\begin{tabular}{|c|c|c|c|c|c|c|}
\hline Trait & Group & Mean & Minimum & Maximum & $\begin{array}{l}\text { Standard } \\
\text { deviation }\end{array}$ & $\begin{array}{c}\text { Variation } \\
\text { coefficient } \\
{[\%]}\end{array}$ \\
\hline 14 & Turfosa form, old trees & $835.6^{\mathrm{a}}$ & 680 & 960 & 69.4 & 8.31 \\
\hline \multirow{3}{*}{$\begin{array}{c}\text { Width } \\
\text { of vascular cylinder } \\
{[\mu \mathrm{m}]}\end{array}$} & Turfosa form, young trees & $776.2^{\mathrm{b}}$ & 624 & 984 & 95.9 & 12.36 \\
\hline & Typical pine, young trees & $850.2^{\mathrm{a}}$ & 724 & 1124 & 113.2 & 13.32 \\
\hline & Typical surrounding pine, old trees & $663.5^{\mathrm{c}}$ & 510 & 862 & 86.5 & 13.03 \\
\hline \multirow{4}{*}{$\begin{array}{c}15 \\
\text { Distance between } \\
\text { vascular bundles } \\
{[\mu \mathrm{m}]}\end{array}$} & Turfosa form, old trees & $259.3^{\mathrm{a}}$ & 144 & 352 & 49.6 & 19.12 \\
\hline & Turfosa form, young trees & $215.9^{\mathrm{b}}$ & 136 & 338 & 54.5 & 25.24 \\
\hline & Typical pine, young treesa & $239.0^{\mathrm{ab}}$ & 170 & 324 & 46.6 & 19.51 \\
\hline & Typical surrounding pine, old trees & $169.5^{\mathrm{c}}$ & 86 & 260 & 41.9 & 24.74 \\
\hline \multirow{2}{*}{$\begin{array}{c}16 \\
\text { Marcet's index } \\
\text { (Marcet 1967) }\end{array}$} & Turfosa form, old trees & $558.9^{\mathrm{a}}$ & 309 & 853 & 125.4 & 22.43 \\
\hline & Turfosa form, young trees & $451.2^{\mathrm{b}}$ & 250 & 721 & 125.9 & 27.91 \\
\hline
\end{tabular}

${ }^{a b c}$ different letters mean significant differences at $\mathrm{P}=0.05$ for Tukey's test

ars (mean 35 years), while their height was from 7 to 11 $\mathrm{m}$ (mean $8.6 \mathrm{~m})$.

\section{Phenotypic characteristics of Scots pines from the population growing on mineral soils in the vicinity of the peat bog}

Typical Scots pine, the old trees

This group consisted of 30 trees having a phenotype of typical Pinus sylvestris L. Selected trees had straightgrown stems and typically developed crowns. Their age ranged from 100 to 150 years, their height did not exceed $35 \mathrm{~m}$ and diameter at breast height was up to $0.5 \mathrm{~m}$.

\section{Methods of measurements}

The preliminary analysis was conducted to estimate the number of needles per an individual necessary to cover the entire variation. Due to lack of differences between ten and five analysed needles, the scheme with five needles per an individual was chosen. Thus, a total of 450 needles from 90 trees, representing four phenotypic groups were analyzed altogether. From each tree five two-year old needles were collected randomly. Cross-sections together with semi-fixed preparations were prepared from each needle. Variation of 16 needle anatomical traits was estimated on the basis of microscopic measurements (Table 1).

The following anatomical needle characteristics were analyzed: the width of needle cross-section defining needle width (trait no. 1), the height of needle cross-section defining needle thickness (no. 2), the ratio of height needle cross-section to its width corresponding to the ratio of needle thickness to its width (no. 3), the number of resin ducts (no. 4), the width of the lumen of the 1 st resin duct (no. 5), the width of the lumen of the 1 st resin duct including sclerenchyma (no. 6), the width of the lumen of the 2 nd resin duct (no. 7), the width of the lumen of the 2 nd resin duct including sclerenchyma (no. 8), the width of the lumen of the 3 rd resin duct (no. 9), the width of the lumen of the $3 \mathrm{rd}$ resin duct including sclerenchyma (no. 10), the thickness of epidermis with cuticula on the flat side of the needle (no. 11), the width of three epidermal cells on the flat side of the needle (no. 12), the height of the vascular cylinder (no. 13), the width of the vascular cylinder (no. 14), the di- stance between vascular bundles (no. 15), Marcet's index ((needle width $\times$ distance between vascular bundles): needle thickness) (no. 16).

The data were analysed using standard statistical procedures in the STATISTICA 8.0 EN software on the basis of means for individuals. Briefly, the basic descriptive statistics for each tree group, means, minima, maxima, standard deviations, coefficients of variation, as well as the F Snedecor test were calculated. Tukey's test was used for multiple comparisons of different groups. Discriminant analysis and coefficients of determination between analyzed traits and discriminant variables, values of the $\mathrm{F}$ statistics and Mahalanobis distances were used to estimate the intra- and interpopulation variation. Mahalanobis distances were used to construct phenograms using Ward's method of grouping and Euclidian distance.

\section{RESULTS}

A comparison of anatomical needle traits between old trees of the turfosa form (Woerl.) growing in the peat bog and old typical pine trees growing on mineral soil in the vicinity of the peat bog

The old trees of the turfosa form from the Gaqzwa peat bog differed significantly from old trees of the typical Scots pine growing on mineral soil in terms of 10 out of 16 analyzed traits (i.e., $62.5 \%$ of traits) as indicated by the analysis of variance and Tukey's test (Table 1). The turfosa form had higher values in relation to nine out of these ten traits thus having $22.5 \%$ wider (trait no. 1) and $19 \%$ thicker needles (trait no. 2) and $33.4 \%$ more resin ducts (trait no. 4). Moreover, the epidermis with cuticula on the flat side of the needle (trait no. 11) was $13.6 \%$ thicker in the turfosa form, three epidermal cells on the flat side of the needle were $11.4 \%$ wider (trait no. 12), the vascular cylinder was $11.5 \%$ higher (trait no. 13) and $20.6 \%$ wider (trait no. 14), the distance between vascular bundles was $34.6 \%$ higher (trait no. 15) as well as Marcet's index was $38.3 \%$ higher (trait no. 16). In contrast, the ratio of needle thickness to its width was $4 \%$ higher for the typical pine (trait no. 3). Statistically significant differences between two compared gro- 
TABLE. 2. Discriminant value of 16 anatomical needle traits estimated by lambda Wilks statistics.

\begin{tabular}{ccc}
\hline Trait & $\begin{array}{c}F \\
\text { statistics }\end{array}$ & Probability \\
\hline 1 & 38.850 & \\
2 & 27.926 & 0.0000 \\
3 & 6.913 & 0.0000 \\
4 & 19.051 & 0.0003 \\
5 & 0.924 & 0.0000 \\
6 & 0.417 & 0.4330 \\
7 & 0.995 & 0.7413 \\
8 & 0.294 & 0.3993 \\
9 & 2.067 & 0.8299 \\
10 & 1.421 & 0.1106 \\
11 & 11.151 & 0.2421 \\
12 & 5.645 & 0.0000 \\
13 & 15.582 & 0.0014 \\
14 & 23.636 & 0.0000 \\
15 & 18.219 & 0.0000 \\
16 & 18.307 & 0.0000 \\
\hline Critical value & 1.93 & 0.0000 \\
\hline
\end{tabular}

TABLE 3. Determination coefficients between 16 anatomical needle traits and the first two discriminant variables.

\begin{tabular}{ccc}
\hline Trait & $\mathrm{U}_{1} 77.1 \%$ & $\mathrm{U}_{2} 13.4 \%$ \\
\hline 1 & 38.65 & 0.93 \\
2 & 28.05 & 0.19 \\
3 & 3.48 & 3.60 \\
4 & 18.26 & 0.43 \\
5 & 0.20 & 0.75 \\
6 & 0.01 & 0.35 \\
7 & 0.11 & 0.77 \\
8 & 0.10 & 0.20 \\
9 & 0.44 & 1.55 \\
10 & 0.17 & 1.26 \\
11 & 11.01 & 0.36 \\
12 & 5.40 & 0.00 \\
13 & 13.27 & 0.56 \\
14 & 22.77 & 1.36 \\
15 & 18.05 & 0.03 \\
16 & 17.69 & 0.31 \\
\hline
\end{tabular}

TABLE 4. Determination coefficients between 10 anatomical needle traits and the first two discriminant variables.

\begin{tabular}{ccc}
\hline Trait & $\mathrm{U}_{1} 78.88 \%$ & $\mathrm{U}_{2} 13.30 \%$ \\
\hline 1 & 50.47 & 1.18 \\
2 & 36.82 & 0.28 \\
3 & 4.48 & 4.71 \\
4 & 22.84 & 0.37 \\
11 & 14.10 & 0.53 \\
12 & 7.25 & 0.01 \\
13 & 18.15 & 0.99 \\
14 & 29.16 & 1.92 \\
15 & 22.71 & 0.10 \\
16 & 22.18 & 0.57 \\
\hline
\end{tabular}

ups of trees were also confirmed by the values of the F Snedecor test for all mentioned traits (Table 2). It should be stressed however, that all these traits in individual groups of analyzed trees exhibited a relatively low variation, as it was confirmed by low values of their variation coefficients (Table 1).

The width and the height of needle cross-section (traits nos 1 and 2) turned out to belong to the most essential para-

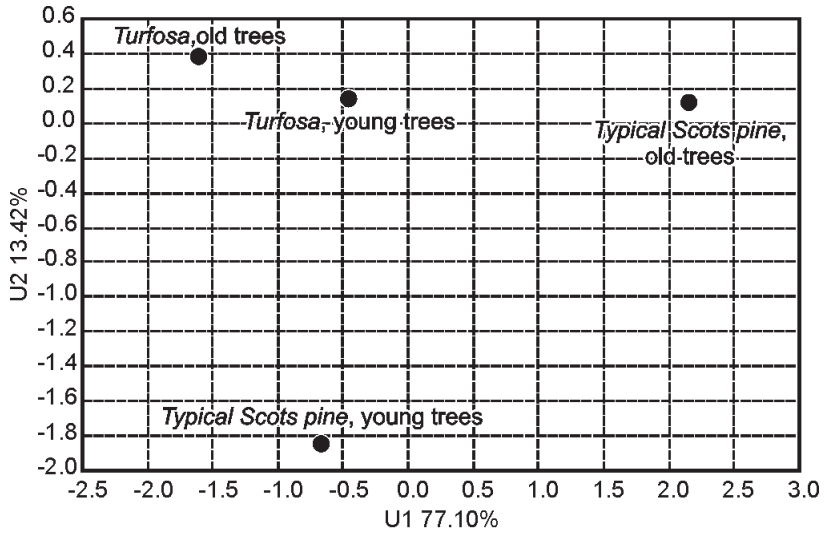

Fig. 1. Scatterplot of the first two discriminant variable containing $90.52 \%$ of total variation based on analysis of 16 needle traits in four Scots pine phenotypic groups.

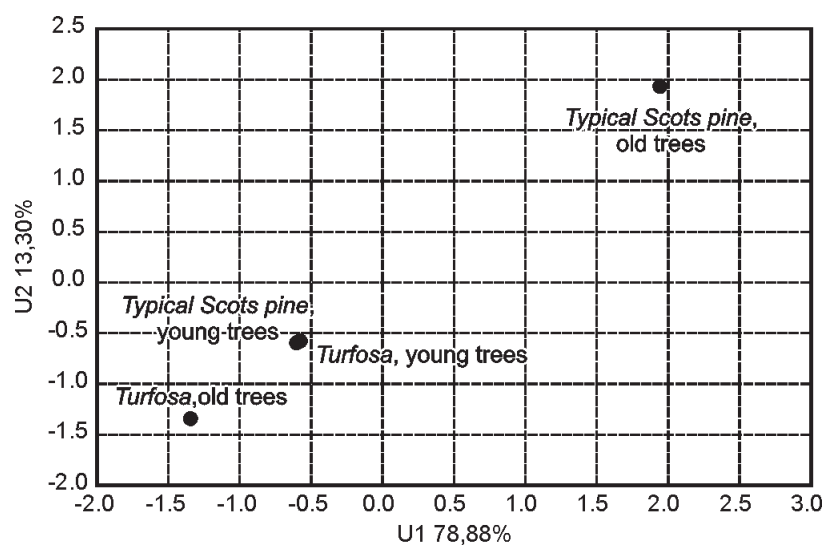

Fig. 2. Scatterplot of the first two discriminant variable containing $90.52 \%$ of total variation based on analysis of 10 needle traits in four Scots pine phenotypic groups.

meters responsible for variation of the compared old trees of the turfosa form and old trees of the typical Scots pine in the analysis of discriminant variables (Tables 3 and 4, Figs 1 and 2). Similarly, the thickness of the epidermis with cuticula (no. 11) on the flat side of the needle and the height and width of the vascular cylinder (traits nos 13 and 14) had a rather considerable share in the generation of variation in the analysis of discriminant variables (Tables 3 and 4). The Marcet's index (trait no. 16) was relatively high in both analyzed groups of trees with values above $20 \%$ (Table 1 ).

The two compared groups of trees did not differ significantly in six successive traits pertaining to the width of the lumen of three resin ducts (traits nos 5 to 10), inside sclerenchyma and outside sclerenchyma (Tables 1 and 2).

A comparison of anatomical needle traits in young trees of typical pine and young trees of the turfosa form growing in the peat bog

The young turfosa form was the most similar to young typical pines growing in the peat bog as it was shown by values of analyzed anatomical traits (Table 1). In the scatterplots they were grouped between the old turfosa form and the old pines growing in the vicinity of the peat bog (Figs 1 and 2). Statistically significant differences confirmed by the Tukey's test were observed only for three traits, the ratio of the height of needle cross-section to its width (an increase by $6 \%$ in the turfosa form) (trait no. 3), the height of the vascular cylinder (an increase by $7 \%$ in the turfosa form) (trait 
no. 13) and the width of the vascular cylinder (an increase by $8.7 \%$ in the typical pine) (trait no. 14 ).

Typical pine, the young trees

The group of these trees differed in terms of ten traits from old trees growing on mineral soil in the area surrounding the peat bog (Table 1). The differences were observed for the same characters as for comparisons between the old turfosa form and old trees of typical Scots pine. Surprisingly, the young typical pines were very alike the old turfosa form as appeared from the similar values of means for seven characteristics. Moreover, means for two of them were intermediate, while one trait had the lowest value. Characteristics exhibiting intermediate values included needle thickness (trait no. 2) and the number of resin ducts (trait no. 4). An increase by $13.3 \%$ and $20.5 \%$, respectively, in relation to the typical Scots pine growing in the area surrounding the peat bog was observed for both traits, while the ratio of the height of needle cross-section to its width was reduced by $10 \%$ (trait no. 3 ).

\section{Turfosa form, the young trees}

The group of these trees in terms of anatomical needle characteristics had statistically significantly lower means as confirmed by the Tukey's test for four traits in comparison to the old turfosa form. Thus the young turfosa trees had $17.6 \%$ fewer resin ducts (trait no. 4), 7.1\% narrower the vascular cylinder (trait no. 14), 16.7\% shorter the distance between vascular bundles (trait no. 15) and 19.3\% lower Marcet's index (trait no. 16) (Table 1). Young trees of the turfosa form differed significantly from old typical pine trees growing in the area surrounding the peat bog in terms of nine traits (with the exception of the ratio of the height of needle cross-section to its width).

\section{A comparison of four analyzed groups of trees from the Gazwa reserve}

The first two discriminant variables based on 16 analyzed traits separated easily each of the analyzed phenotypic groups of pines. The old turfosa form and the typical form of old pine trees growing in the area surrounding the peat bog were located opposite, while younger pines of the turfosa form and young typical pine trees occupied the intermediate position (Figs 1 and 2). The intermediate character of young trees from the group of the turfosa and typical pine forms was clearly visible (Fig. 2), while analyzing their location on the axis of the first discriminant variable. This variable was affected to the highest degree by such traits as needle width (trait no. 1), needle thickness (no. 2), the number of resin ducts (no. 4), the width of the vascular cylinder (no. 14) and the distance between vascular bundles (no. 15) (Table 3). The described variation was confirmed by Mahalanobis distances which differentiated old trees of Scots pine surrounding the peat bog from each group of trees inhabiting the Gązwa peat bog i.e., old trees of the turfosa form, young trees of the turfosa form and young trees of the typical pine. These two latter groups of trees from peat bog were similar in terms of most analyzed biometric traits (Table 5). The intermediate position of the young trees of the turfosa form was clearly visible in the phenogram based on Mahalanobis distances thus confirming the hybrid origin of these trees (Fig. 3).
TABLE 5. The squared Mahalanobis distances between four groups of Scots pine based on the 16 anatomical needle traits.

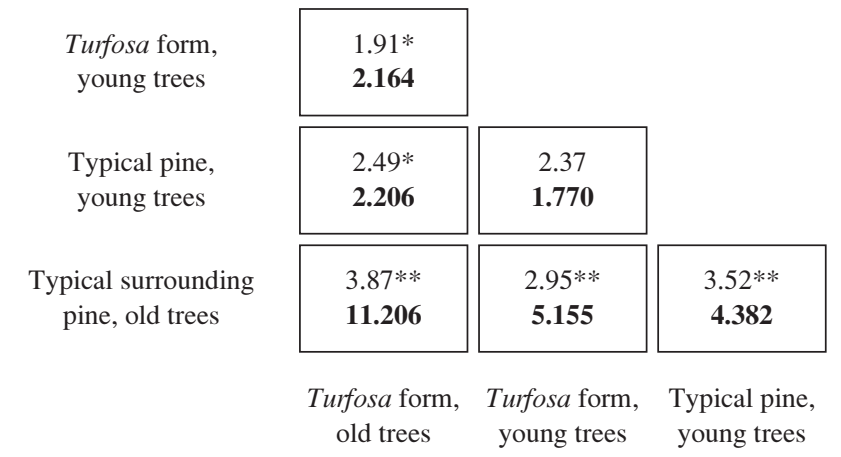

Bold - Mahalanobis distance, $*(\mathrm{p}<0.05), * *(\mathrm{p}<0.01)$

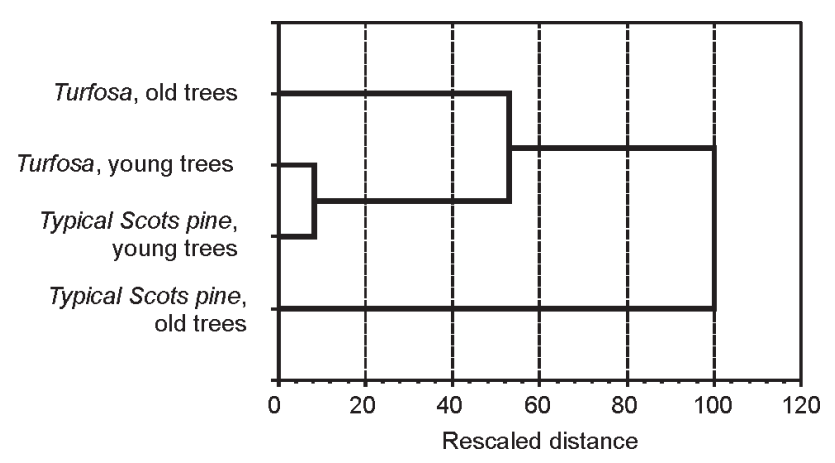

Fig. 3. Phenogram of the four phenotypic Scots pine groups based on Mahalonobis distances.

\section{DISCUSSION}

The present demographic situation of Scots pine in the Gązwa peat bog reserve results from the recent history, initiated in 1860 by the drainage of Lake Stama, adjacent to this peat bog (Uggla 1968). As late of mid-1900's the Gązwa peat bog was overgrown only by sparsely distributed specimens of Pinus sylvestris f. turfosa (Młynek and Polakowski 1962). Successive land reclamation works performed in the vicinity of the reserve, probably in the 1970's, and a general lowering of the groundwater level have resulted in disturbances of water conditions in the peat bog following by habitat alterations. As a result of these changes a spontaneous succession of the typical forms of Scots pine has occurred. At present, they are represented by specimens included in the group of the typical pine, young trees.

Scots pine inhabiting the Gązwa peat bog is characterized by a very diverse demographic structure and considerable phenotypic variation. At present the dominant element in the stand consists of pines aged 20-40 years, with a habitus characteristic for the typical form. Seedlings and young undergrowth are found in very large numbers, while older trees with a morphotype typical of Scots pine, aged approximately 55 years, are scarce. Much older pines, aged up to 250 years, of the turfosa phenotype are also less numerous. A significant group is composed of pines of different age, up to several dozen years old, representing a wide range of morphological variation. All these groups, isolated on the basis of morphological traits, form a panmictic population, reproducing intensively and overgrowing the Gązwa peat bog.

Dendrometric analyses have shown that pines of the turfosa phenotype in the age group of 30-85 years are fivefold 
shorter than pines with the typical morphotype aged 20-55 years, growing in the immediate vicinity in this peat bog. The mean height of both categories of these pines was 1.6 $\mathrm{m}$ and $8.6 \mathrm{~m}$, respectively (Polok et al. 2005). Also stem diameter in the turfosa form was over twofold smaller, amounting to $4.2 \mathrm{~cm}$ in comparison with $9.2 \mathrm{~cm}$ in pines with a typical phenotype.

The smaller stem diameter in the turfosa form is correlated with a slow rate of its increment in diameter. Analyses of annual increments in diameter in the turfosa form at the age of 34 years and those of the typical pine, aged 41 years, have shown that in the former they were much smaller and uniform over the years, oscillating around 0.3 $\mathrm{mm}$ annually. In turn, in the typical pine these increments are on average threefold bigger and exhibit a wide amplitude in individual years, ranging from $0.4 \mathrm{~mm}$ to $3 \mathrm{~mm}$. Similarly, low and stable rates of annual increments have been recorded in the turfosa form aged 217 years (Polok et al. 2005).

Presumably, differences between the turfosa form and the typical pine are determined genetically because both phenotypic groups are found in the same peat bog, which considerably reduces the effect of environmental variation on values of analyzed traits. This might mean that the turfosa form is a pine ecotype adapted to peat bogs, which it has inhabited for several thousand years. The typical pine is also found in high peat bogs or even transitional moors, where it forms dwarf forms, most frequently not reproducing generatively. Observations from other peat bogs confirm that primarily young pines grow there and the replacement of generations occurs relatively fast. These pines, even if they live longer, due to fast growth rates and considerable height are incapable of surviving in the bog soil with a high groundwater level and thus they die or fall. Such a situation may be observed e.g., in the Redykajny peat bog reserve near Olsztyn (Zielinski R., personal communication).

The distinctiveness of the turfosa form in terms of dendrometric traits is also confirmed in morphological (Polok et al. 2005) and anatomical needle traits. However, the turfosa form differs much more from pines with a typical phenotype growing on mineral soils in areas surrounding the peat bog than from pines with a typical phenotype found in the peat bog. The latter category and younger pines with the turfosa phenotype in terms of values of analyzed traits occupy the intermediate position, which may indicate their hybrid character.

Needles of old pines of the turfosa form are significantly shorter $(41.7 \mathrm{~mm}$ in comparison with $58.6 \mathrm{~mm}$ in typical Scots pine) and have a bigger number of stomata rows on the convex side of needles in comparison to typical pines growing in mineral soils in areas surrounding the peat bog (Polok et al. 2005). At the same time these needles are thicker, have a bigger number of resin ducts, a thicker epidermis with cuticula on the flat side of the needle, a bigger width of three epidermal cells on the flat side of the needle, bigger height and width of the vascular cylinder, a bigger distance between vascular bundles and a higher Marcet's index. Moreover, in the turfosa form the area of needle cross-section is by $38 \%$ bigger and the area of vascular cylinder cross-section by $30 \%$ bigger. One of the more discriminant traits is the number of resin ducts, which in the turfosa form is by $33.4 \%$ higher. On the other hand, peat bog populations in the Tuchola Forests have a much lower value of this trait (Urbaniak et al. 2003), which indicates that the higher number of resin ducts is rather connected with a specific genotype than with the presence of pine in the peat bog in itself.

The typical pine trees inhabiting the peat bog differ in terms of all the above mentioned characteristics from the typical Scots pines, growing in mineral soils in areas surrounding the peat bog. Means for most of these traits (70\%) are similar to values found in the old trees of turfosa form. It seems likely that the young, typical pine trees are hybrids between the typical pine growing in areas adjacent to the peat bog and the old turfosa form, owing to which their adaptive value in this habitat has increased. Similarly, the hybrid nature is also found in the group of young trees of the turfosa form, as it is suggested on the one hand by their distinctiveness in relation to the old turfosa form in terms of four anatomical needle traits, and on the other hand by their similarity to young trees of the typical pine in seven quantitative traits, confirmed also by their intermediate position in the dendrograms.

The presented data on the hybrid origin of the new generation of pines confirm a more generally observed phenomenon of invasion of hybrid origin species onto anthropogenically disturbed sites (Perron and Bosquet 1997; Neuffer et al. 1999; Lamont et al. 2003). So far this process has been found mainly in case of drastic environmental changes. The reported example from the Gązwa reserve shows that even a slight interference into a stable natural ecosystem may also cause a similar effect.

Analysis of DNA markers confirmed genotypic uniqueness of the old turfosa form (Polok et al. 2005). Many diagnostic loci are found in this form, together with a considerable decrease in the share of polymorphic loci to $2 \%$ in relation to $29 \%$ in pine with a typical habitus. The reduced level of variation in the turfosa form is most probably connected with its adaptation to extreme environmental conditions. Probably, it also results from the effect similar to inbreeding depression as a result of a small size of the population inhabiting the peat bog in the past. The reduction of genetic variation is frequently observed in populations with a reduced size (Nunney and Elam 1994), in which additionally a tendency to inbreeding depression is also found (Falconer 1989).

The hybrid nature of young trees growing in the peat bog, both those with the phenotype of the typical pine and the turfosa form, is also visible in DNA fingerprints. Both these categories of trees have bands specific both for the old turfosa form and the typical pine from the surrounding areas (Zielinski et al. 2007). In the Gązwa peat bog, hybridization of pines with a typical morphotype with the turfo$s a$ phenotype threatens the survival of this unique and possibly relict morphotype, of which old turfosa trees are probably the last generation.

\section{CONCLUSIONS}

1. The old turfosa form from the Gązwa reserve is a unique and relict peat bog pine, as it is shown by the differences in 10 out of 16 analyzed needle traits in comparison to pine with a typical morphotype growing in the areas surrounding the peat bog. 
2. The young typical pine has adapted to conditions found in the peat bog thanks to hybridization with the turfosa forms inhabiting the peat bog.

3. The young turfosa form differs from the old turfosa form and it is a hybrid origin.

4. The old turfosa form from the Gązwa reserve is a threatened ecotype due to its hybridization with pines from the population surrounding the peat bog.

\section{ACKNOWLEDGEMENT}

This work was supported by the European Community Project: Marie Curie Warmia and Mazury University in Olsztyn Host Fellowships for the Transfer of Knowledge, GenCrop coordinated by Department of Genetics, Contract No. MTKD-CT-2004-509834.

The authors would like to thank the anonymous reviewer for useful comments.

\section{LITERATURE CITED}

BOBOWICZ M.A. 1990. Analiza struktury morfologicznej sosny zwyczajnej Pinus sylvestris L. z „Boru na Czerwonem” w Kotlinie Nowotarskiej. Wyd. Naukowe UAM, Poznań. (in Polish with English summary).

FALCONER D.S. 1989. Introduction to quantitative genetics. 3rd ed. Longman. London.

GIERTYCH M. 1979. Summary of result on Scots pine (Pinus sylvestris L.) height growth in IUFRO provenance experiments. Silvae Genetica 28 (4): 136-152.

HERBICHOWA M. 1998. Ekologiczne studium rozwoju torfowisk wysokich właściwych na przykładzie wybranych obiektów z środkowej części Pobrzeża Bałtyckiego. Wydawnictwo Uniwersytetu Gdańskiego, Gdańsk. (in Polish).

HUNTLEY B., BIRKS H.J.B. 1983. An atlas of past and present pollen maps for Europe: 0-13 000 years of age. Cambridge University Press.

JASNOWSKI M., JASNOWSKA J., MARKOWSKI S. 1968. Ginące torfowiska wysokie i przejściowe w pasie nadbałtyckim Polski. Ochrona Przyrody 33: 67-124. (in Polish).

KONDRACKI J. 1998. Geografia regionalna Polski. Wydawnictwo Naukowe PWN, Warszawa. (in Polish).

LAMONT B.B., ENRIGHT T. HE. N.J., KRAUSS S.L., MILLER B.P. 2003. Anthropogenic disturbance promotes hybridization between Banksia species by altering their biology. J. Evol. 16 (2003): 551-557.
MARCET E. 1967. Über den Nachweis spontaner Hybriden von Pinus mиgo Turra und Pinus sylvestris L. auf Grund von Nadelmerkmalen. Bern. Schweiz. Bot. Ges. 77: 314-361.

MŁYNEK T., POLAKOWSKI B. 1962. Zespoły roślinne rezerwatu torfowiskowego „Gązwa”. Zeszyty Naukowe Wyższej Szkoły Rolniczej w Olsztynie 14(235): 317-329. (in Polish).

MOJSKI J.E. 1993. Europa w plejstocenie. Ewolucja środowiska przyrodniczego. Wyd. PAE. Warszawa. (in Polish).

NEUFFER B., AUGE H., MENSCH H., AMARELL U., BRANDL R. 1999. Spread of violets in polluted pine forests: morphological and molecular evidence for the ecological importance of interspecific hybridization. Mol. Ecol. 8 (1999): 365-377.

NUNNEY L., ELAM D.R. 1994. Estimating effective population size of conserved populations. Conserv. Biol. 8: 175-184.

PERRON M., BOSQUET J. 1997. Natural hybridization between black spruce and red spruce. Mol. Ecol. 6 (1997): 725-734.

POLOK K., PISAREK W., URBANIAK L., KOKRZEWA K., ZIELINSKI R. 2005. Genetic characteristics of Pinus sylvestris f. turfosa (Woerl.) from the Gązwa reserve, north-eastern Poland. In: W. Prus-Głowacki and E. Pawlaczyk (eds), Variability and Evolution - New Perspectives. Adam Mickiewicz University, Poznań, pp. 225-239.

STASZKIEWICZ J. 1970. Systematyka i zmienność. In: S. Białobok (red.), Sosna zwyczajna Pinus sylvestris L. Nasze drzewa leśne. PWN, Warszawa-Poznań, pp. 55-77. (in Polish).

STASZKIEWICZ J. 1993. Sosna w historii naszych lasów. In: S. Białobok, A. Boratyński, W. Bugała (eds). Biologia sosny zwyczajnej. Wyd. Sorus. Poznań-Kórnik, 11-31. (in Polish).

SZYMAŃSKI S. 1996. Ekologia sosny zwyczajnej (Pinus sylvestris L.). Sylvan, 140 (11): 5-9. (in Polish).

TOBOLSKI K. 2003. Torfowiska na przykładzie Ziemi Świeckiej. Towarzystwo Przyjaciół Dolnej Wisły, Świecie. (in Polish).

TOBOLSKI K. 2006. Lakes and mires of Bory Tucholskie National Park. Oficyna Wydawnicza FOREST, Charzykowy.

UGGLA H. 1968. Bagienne i murszowe gleby gytiowiska Gazwa. Roczniki Gleboznawcze, 18 (2): 369-414. (in Polish).

URBANIAK L. 1998. Zróżnicowanie geograficzne sosny zwyczajnej (Pinus sylvestris L.) z terenu Eurazji na podstawie cech anatomicznych i morfologicznych igieł. Wyd. Naukowe UAM. (in Polish with English summary).

URBANIAK L, KARLIŃSKI L., POPIELARZ R. 2003. Variation of morphological needle characters of Scots pine (Pinus sylvestris L.) populations in different habitats. Acta Soc. Bot. Pol. 72 (1): 37-44.

ZIELINSKI R., OSMĘDA J., URBANIAK L., POLOK K. 2007. Molecular characteristics of Pinus sylvestris L. ancient ecotype from the Gazwa peat bog reserve. Polish Bot. Journal, Polish Bot. Studies. (in press). 